УДК: 37.041[159.923.5+37.061]:372.854

DOI: 10.26697/ijes.2019.2.03

\section{Психолого-педагогічні формування готовності майбутнього викладача хімії до творчої самореалізації у професійній діяльності}

Дубова Л. В. ${ }^{1}$

${ }^{1}$ Національний технічний університет

“Харківський політехнічний інститут”, Україна

\section{Резюме}

Вступ:

У вдосконаленні освітньої практики особлива роль відводиться педагогу, від діяльності якого залежить ефективність проведених в країні реформ, що обумовлює необхідність якісної зміни підготовки майбутніх фахівців в галузі освіти. Сьогодні суспільство відчуває потребу в наявності педагогів, здатних забезпечувати високі навчально-виховні результати. Таке завдання може бути вирішене лише в разі сформованої готовності до творчої діяльності якомога більшої кількості випускників вузів.

Мета дослідження - теоретично обгрунтувати та виявити сукупність психолого-педагогічних умов формування готовності майбутнього викладача хімії до творчості у професійній діяльності.

Виняткову роль у формуванні готовності майбутнього викладача хімії до творчості у професійній діяльності відіграє освітнє середовище, яке має бути не тільки сприятливим для розвитку творчості суб'єкта пізнання, а й підкріплювати креативність поведінки, надавати зразки творчості, розвивати потребу до творчої праці.

\section{Методи: \\ Для реалізації мети та завдань даної роботи були використані наступні методи дослідження: теоретичний аналіз і узагальнення літературних джерел; абстрагування; уявне моделювання; сходження від абстрактного до конкретного.}

\section{Результати:}

Психолого-педагогічними умовами, що сприяють формуванню готовності викладача хімії до творчої професійної діяльності, є:

1) організація навчання на основі особистіснодіяльнісного та індивідуально-диференційованого підходів;

2) введення в зміст педагогічної освіти інваріантного i варіативного компонентів, що включають в себе необхідний і достатній обсяг знань для здійснення творчої діяльності;

3) облік особистісного потенціалу педагога в освоєнні способів творчої діяльності;

4) організація різнорівневих видів самостійних робіт для здобувачів освіти.

Основною та найважливішою умовою творчої самореалізації педагога $\epsilon$ його професійна підготовленість.
Особистісними якостями, що сприяють формуванню готовності майбутнього педагога до творчості у професійній діяльності, є: мотиваційні; інтелектуальні (знання про сутність і компонентний склад творчої діяльності); емоційно-вольові (почуття, потреби, бажання та ін.); професійно ціннісні (цінності - цілі, цінності - зміст, цінності методи, цінності - засоби).

3 огляду на основні сфери педагогічної діяльності, слід виділяти три групи особистих якостей педагога - соціально-моральна (світогляд, ціннісні орієнтації, переконання і ідеали), істиннопедагогічна (інтерес до професії, педагогічні схильності і наміри) i пізнавальна (потреба в дослідницькій діяльності, рефлексії, саморозкриття і самореалізаціі).

Творча спрямованість педагога має змістовні (повнота i рівень) i динамічні (інтенсивність, тривалість і стійкість) характеристики.

Одним 3 важливих напрямів розвитку творчої спрямованості викладача хімії є розвиток потреби до творчості через збагачення мотивів, професійно значущих цінностей, особистісних смислів і здібностей.

\begin{abstract}
Висновки:
На основі вищесказаного можна виділити наступні етапи процесу формування готовності викладачів хімії до творчої професійної діяльності: 1) орієнтуючий (спонукання до творчості);

2) інноваційний (освоєння понятійних систем, що розкривають різні аспекти творчої особистості та професійної компетентності педагога-творця, включення в рішення творчих педагогічних задач, пов'язаних 3 різними формами і видами реальної професійної діяльності);

3) прогностичний (експертна оцінка та самооцінка готовності до творчості в різноманітних видах педагогічної праці).

Отже, творчість займає важливу позицію в діяльності вчителя i виконує певні функції: формуючі, дидактичні, психологічні, варіативні. Вона $\epsilon$ необхідною умовою при самореалізації особистості викладача.

За даних умов виникає потреба підготовки викладача хімії до усвідомлення свого рівня творчої педагогічної діяльності, формування у нього потреби аналізувати власний педагогічний досвід i впроваджувати педагогічний досвід інших 3 урахуванням своєї творчої індивідуальності.
\end{abstract}

Інформація про автора:

Дубова Лілія Василівна - Національний технічний університет "Харківський політехнічний інститут", Харків, Україна.

Автор-Кореспондент:

Дубова Лілія Василівна

Email Автора-Кореспондента:

lilit03051992@gmail.com 